\title{
Behavioral Customer Loyalty in Online Shopping: The Role of E-Service Quality and E-Recovery
}

\section{Majid Mohammad Shafiee ${ }^{1}$ and Negin Ahghar Bazargan ${ }^{2}$}

\author{
${ }^{1}$ University of Isfahan, Department of Management, Isfahan, Iran, m.shafiee@ase.ui.ac.ir \\ 2 University of Isfahan, Department of Management, Isfahan, Iran, negin.b1990@pds.ui.ac.ir
}

Received 13 February 2017; received in revised form 12 July 2017; accepted 25 August 2017

\begin{abstract}
Nowadays, the internet has become a suitable platform for the trade of products and services. Online shopping transactions are carried out without face-to-face contact; thus, various factors can affect customers' purchase intentions. In addition to aesthetics and ease of use, trust is a critical factor which allows customers to choose an online store. Online merchants need to find ways to keep trusting customers satisfied and loyal. This paper investigates how customer loyalty can be created and/or enhanced in online shopping. The statistical population of the study includes the customers of several online stores in Iran. Data collection is carried out using a questionnaire. The results indicate that information security and website performance influence eservice quality both positively and directly. Also, responsiveness, compensation, and contact positively influence e-recovery. E-recovery has positive impact on e-loyalty, which in turn significantly affects online repurchase.
\end{abstract}

Keywords: E-shopping, E-loyalty, E-service quality, E-recovery, Online repurchase intention 


\section{Introduction}

Throughout history, human beings have conducted various types of exchanges to meet their needs. Technological advances allowed the creation of virtual communities, wherein individuals are able to make transactions of similar settings. Typically, members of virtual communities are not acquainted as they are only connected through information technologies [31], [60], [65]. Virtual communities are commonly used for the exchange of information, discussion, and entertainment among others. Over the past two decades, virtual communities have also been used to trade services and products [13]. This type of trade, conducted over the Internet through the exchange of electronic data, is known as Electronic Commerce (EC) [24]. With advances in technology, modern trading activities have become increasingly efficient. However, the role of trust is more critical in EC.

By establishing trust in online environments, customers are encouraged to adopt online shopping [62]. Loyal customers generate lasting revenue and profits for a business and reduce the costs associated with acquiring new customers. In order to entice customers to return, the company needs to keep them satisfied by providing attractive services and offers, which can be achieved through high-quality service. Furthermore, companies need to formulate strategies to compensate for deficient services and eliminate their shortcomings so that, despite receiving poor service on some occasions, customers remain with the company. Studies show that quality of service leads to customer satisfaction [20], which in turn results in loyalty [34], [42], and repeat business.

Considering an online shopping content, in this study, we examine the role of service quality and quality improvement in customer acquisition and retention. Providing better service quality increases customer satisfaction with an online store, which results in repeat business as well as customer loyalty [3]. This paper aims to investigate the impact of e-service quality and e-recovery, which refers to the reaction of a company to a service failure [26], on customer loyalty in online stores. In doing so, as a first step, existing literature was reviewed to find relevant models and indices. Then, by conducting a field study and using expert opinions, the indices were adjusted and adapted. Thereafter, the required data were collected using a questionnaire. For data collection purposes, the questionnaire was distributed among 50 members of the studied population. Finally, the collected data were analyzed. This paper employs partial least squares-structural equation modeling (PLS-SEM) to determine model fit and test the postulated hypotheses. The fact that online shopping is a recent phenomenon in Iran and its culture is in the developing stages limits our study on topic. The findings of our study as well as those of other studies are quite valuable in that they can be used to increase sales and customer loyalty in online stores.

This study is expected to provide contribution in form of better explanation of the role of e-service quality and erecovery in behavioral customer loyalty in online shopping among Iranian consumers. In this paper, we developed a novel measure which is different from those proposed by Parasuraman [50]. The measure is more concise and can prove effective in online studies.

\section{Literature Review}

Although quite a large body of literature has been devoted to both online and offline loyalty, studies that focus on the role of online services, especially quality and recovery of services, in enhancing loyalty and improving online repurchase intentions are scarce. In the following, a number of studies similar to this paper are briefly reviewed.

Lin and Sun [42] presented an integrated model of factors that influence satisfaction and loyalty in online shopping. The study had four major findings: (1) Customer e-satisfaction has a significant positive impact on customer e-loyalty; (2) E-loyalty and e-satisfaction are both directly influenced by technology acceptance factors; (3) Website service quality has a direct positive impact on both e-satisfaction and e-loyalty; and (4) Specific holdup costs - defined as "particular intangible and tangible assets made in the course of the buying and selling" [12] - can positively influence customer e-satisfaction and e-loyalty. A sustainable loyalty model for customers of e-retailers was proposed by Hamidizadeh et al. [30]. All of the studied variables, namely trust, secure payment, perceived value, customer satisfaction, customization, ease of purchase, brand credibility of the website, and interactive purchase, were found to be significantly related to loyalty. Furthermore, Seyed Naghavi and Shakiba [57] devised a model for identifying the factors that affect the process of loyalty formation in online stores. They concluded that e-satisfaction, online store quality, and e-trust are among the most important factors that influence customer e-loyalty. Attafar and Mansouri [4] designed a model for improving customer loyalty among customers of online stores. The authors argued that improved customer loyalty is a key indicator of sustained success for online stores. A total of 21 factors were found to influence e-loyalty, which can be divided into three categories: customer service, website design, and trust.

In a study on the impacts of e-service quality and e-satisfaction on e-loyalty in online banking, Ariff et al. [3] demonstrated that system availability, privacy, responsiveness, and website aesthetics impact e-service quality in the banking industry. These factors in turn influence e-loyalty and e-satisfaction. Moreover, e-service quality and perceived value have been shown to be related to loyalty in e-retailing [67]. Investigating the relationship between trust and online repurchase intention among tourists in Malaysia, Razak et al. [52] found that online trust affects 
repurchase intention in the tourism industry. Lee et al. [38] studied two types of trust in virtual communities to differentiate their user acceptance processes by using the Technology Acceptance Model. The study provides an understanding of the kind of trust that virtual community managers need to develop to induce members to use their sites more, so they can manage the communities more efficiently.

Satisfaction literature strongly supports the idea that increased satisfaction with a service encounter leads to an increased propensity to return to the same service provider. Khan et al. [35] studied the factors affecting satisfaction and repurchase intentions in online stores. Customer satisfaction was found to be dependent on customer perceptions as well as the online store experience. According to the results, a total of seven factors (i.e. price, ease of purchase, product information, return policies, financial risks, product risks, and delivery risks) significantly impact customer satisfaction and repurchase intentions in online stores. Hsu et al. [33] studied the relationship between richness of information and satisfaction of participants in online communities. The results indicate that richness of communication channels and completeness of information lead to trust and satisfaction of participants. Cristobal et al. [15] found that perceived quality is a multidimensional construct consisting of web design, customer service, assurance and order management. Perceived quality influences satisfaction and satisfaction influences consumer loyalty. Moreover, no differences in the conclusions were observed if the total sample was divided into buyers and information seekers.

In Iran, online shopping is a relatively new phenomenon. Thus, many aspects of the field have received little research attention. Furthermore, prior works in Iran and other countries (e.g. [30], [42], [58]) explore factors that drive online shopping and influence customer satisfaction; however, this paper concerns the impact of online services, including service quality and improvement, on customer loyalty and online repurchase intentions in an Iranian population.

\section{Theoretical Background}

In this section, existing literature is briefly reviewed by defining virtual communities. Then electronic loyalty and its constituent components i.e. e-service quality and e-recovery are described without going into much detail. In addition, an overview of online repurchase intention is given.

\subsection{Virtual Community}

Recently, research interest in the concept of virtual community or social networks has increased. A virtual community is defined as a group of individuals with shared interests and activities who communicate for a certain amount of time over the Internet through a common location or mechanism [53]. In another definition, a virtual community refers to a set of individuals, not bound by geographical, physical, or ethnical limitations, who communicate through electronic means to share interests [54]. Virtual communities enable users to conduct business activities through the Internet for instance to buy and sell goods and services. This ability has attracted considerable attention. Firms that are involved in this type of business are known as EC companies. By identifying the factors that drive customers to websites, retention rates can be increased. EC entrepreneurs encourage users to remain on their websites for longer durations since they play a critical role in the marketing of the website [38]. This is because, in addition to making further purchases, engaged users talk about their purchases with other customers on the site, discuss promotional banners, give product recommendations [51], and persuade other patrons to shop on the website, which will ultimately increase profitability.

\subsection{E-Trust}

In offline contexts, trust has been extensively studied since the 1950s [14]. The topic has been explored in a variety of fields including philosophy [32], sociology [55], natural sciences [16], management [46] and marketing [22]. Thus, collectively, there is ample literature on the topic of trust.

Definitions of the concept vary greatly. However, Luhmann seems to present the most descriptive and comprehensive definition. According to the author, trust is a solution for risk [43]. The notion of online trust augments existing knowledge on trust with other valuable findings. Essentially, trust results from a set of safe beliefs. The ecommerce context includes a large number of factors, which may influence customer trust, and the concept is a critical determinant of accepting e-commerce development [64].

\subsection{E-Service Quality}

E-service quality is an important topic in the field of marketing. Electronic services are based on mutual flows of information between customers and service providers, making them different from traditional services. High-quality Internet services have numerous advantages and may lead to efficiency and benefits [9], [19]. Providing online services is now more critical than ever for retaining customers. The sense of loyalty instilled by the exceptional level of services provided by a company persuades customers return to a website. By giving high-quality electronic services, firms can gain competitive advantage [49]. Service quality greatly affects customer satisfaction [1]. 
Moreover, improving service quality with the objective of satisfying and retaining customers is a serious challenge for many companies [40]. Studies indicate that quality of electronic services is dependent on two factors: (1) security and confidentiality of information and (2) website performance. Customers expect adequate performance and information privacy from an EC website [50]. Table 1 presents the factors influencing the dimensions of these two factors. It is notable that Parsuraman's approach is different from ours. Our initial exploratory factor analysis revealed that the dimension and its corresponding items are distinct from service quality (as in Durmus et al. [19]). However, our findings do not contradict those of Parsuraman; rather, the two sets of findings tend to complement each other.

Table 1: Dimensions of e-service quality

\begin{tabular}{|c|c|c|c|}
\hline Variable & Dimension & Factor & Reference \\
\hline \multirow{8}{*}{$\begin{array}{l}\text { E-Service } \\
\text { Quality }\end{array}$} & \multirow{4}{*}{$\begin{array}{l}\text { Information } \\
\text { Security \& } \\
\text { Confidentiality }\end{array}$} & Keeping information about online shopping behaviors secure. & \multirow{8}{*}{$\begin{array}{l}\text { Durmuş et al. } \\
\text { [19] }\end{array}$} \\
\hline & & Keeping customer banking information secure. & \\
\hline & & Strong commitment to on-time delivery & \\
\hline & & Preventing customer information from being shared with other websites. & \\
\hline & \multirow{4}{*}{$\begin{array}{l}\text { Website } \\
\text { Performance }\end{array}$} & Simplifying the process of finding products on the website. & \\
\hline & & The ability to quickly conduct a transaction. & \\
\hline & & The ability to easily browse a website. & \\
\hline & & Structure and organization of information on the website. & \\
\hline
\end{tabular}

Based on the literature, the following are hypothesized:

H1. Information security positively influences e-service quality in online stores.

H2. Website performance positively influences e-service quality in online stores.

\subsection{E-Recovery}

E-recovery refers to the reaction of a company to a service failure [26] in order to ease dissatisfaction and ultimately retain customers [47]. Companies need to find ways to make dissatisfied customers happy. Minor and ineffective improvements only lead to recurring dissatisfaction among customers. Furthermore, such incidents cause customers to share negative word-of-mouth, revealing the shortcomings of the organization to competitors [39]. Also, if asked to provide feedback immediately after a bad service experience, most customers give very low ratings [45]. Therefore, in order to be effective, recovery measures need to be supported by senior management. Although companies strive to create long-term relationships with their customers, service failures and the subsequent attempts to improve shortcomings may deeply affect customer satisfaction and the quality of their relationships with the organization. Therefore, service quality may be claimed to significantly affect customer satisfaction [19], [67]. A survey of literature indicates that e-recovery is influenced by three factors: responsiveness, compensation, and contact. In order to have the damages incurred by service failure, at least, partially compensated, customers expect companies to provide services in each of the mentioned areas. Table 2 details the dimensions of each factor.

Table 2: Dimensions of e-recovery and factors influencing them

\begin{tabular}{|c|c|c|c|}
\hline Variable & Dimension & Factor & Reference \\
\hline \multirow{11}{*}{ E-recovery } & \multirow{5}{*}{ Responsiveness } & Providing adequate alternatives for returning products. & \multirow{11}{*}{$\begin{array}{l}\text { Durmuş et al. } \\
\text { [19] }\end{array}$} \\
\hline & & Providing acceptable information on how unsuccessful transactions are handled. & \\
\hline & & Offering good guarantees. & \\
\hline & & Handing product returns well. & \\
\hline & & Taking care of potential problems. & \\
\hline & \multirow{3}{*}{ Compensation } & Providing compensation in case the ordered items are not delivered on time. & \\
\hline & & Collecting items that need to be returned from the customer's home or business. & \\
\hline & & Providing compensation in case of problems. & \\
\hline & \multirow{3}{*}{ Contact } & Having customer service representatives available online. & \\
\hline & & Providing the ability to directly speak to a live person in case of any problems. & \\
\hline & & Providing a contact number to reach the company. & \\
\hline
\end{tabular}

Thus, we present the following hypotheses:

H3. Responsiveness positively influences e-recovery in online stores.

H4. Compensation positively influences e-recovery in online stores.

H5. Contact positively influences e-recovery in online stores. 


\subsection{E-Loyalty}

Loyalty in fact refers to having a positive attitude toward a product or brand, which induces supportive behavior from the customer. Attitudinal loyalty is essentially customer commitment and trust while behavioral loyalty is grounded in repeat purchases. In this paper, loyalty refers to behavioral loyalty [21].

With the unprecedented growth of EC, the notion of e-loyalty has turned into a major challenge for many virtual communities. E-loyalty refers to desirable customer attitudes in EC, which lead to repeat purchases [56]. In other words, e-loyalty is the customers' favorable attitudes toward an electronic business, resulting in repurchasing behavior [56]. The emergence and development of Business to Customer (B2C) EC has intensified the need to establish a context of trust in a website. Many B2C models stress the need to find adequate numbers of customers before gaining lifelong benefits from each of those loyal customers [62]. In general, loyalty leads to satisfaction; however, satisfaction does not necessarily ensure loyalty. Thus, an asymmetric relationship exists between the two [3]. Since unsatisfied customers have an array of choices, the phenomenon is exceedingly important in online shopping centers. In other words, unsatisfied customer can easily go to competitors for their needs; therefore, it is crucial for any company to satisfy its customers and make them loyal. Studies show that customers with positive attitudes toward a brand tend to remain loyal [5]. E-loyalty is a main variable in this study, which is composed of several dimensions. Subsequent to reviewing extant literature on the topic, in this paper, the indices of e-loyalty by Parasuraman [50] were used, as shown in Table 3. A survey of literature shows that customer loyalty in online shopping is impacted by a number of factors. In this paper, e-service quality and e-recovery [19] are studied.

A variety of other factors, including Internal Measure of service quality (INTQAUL) [10], (Extended Web Assessment Method) EWAM [28], and Site Quality (SITEQUAL) [66], influence e-loyalty. However, the nature of this study does not call of their application. After reviewing available literature and the different scales on the topic (e.g. [19], [10]), less significant dimension were eliminated. Since Iranian populations tend to ignore long questionnaires, thus, only the most important dimensions were retained. The mentioned items such as technology readiness, the unified theory of acceptance and use of technology (UTAUT), e-commerce acceptance and usage, and task-technology fit combined with technology acceptance model (TTF-TAM) are obtained via exploratory factor analysis and expert opinions about online stores are also applied. Furthermore, overlap is also observed in some previous studies and this is due to the inherent characteristics of social science studies. We also used discriminant validity to reduce the overlap, which is evident in the findings.

Table 3: Factors influencing e-loyalty

\begin{tabular}{|l|l|l|}
\hline Variable & Factor & Reference \\
\hline \multirow{4}{*}{ E-Loyalty } & Encouraging friends to use a website & \\
\cline { 2 - 2 } & Recommending the website to others. & Parasuraman \\
\cline { 2 - 2 } & Saying positive things about the site to others. & \\
\cline { 2 - 3 } & Considering the site to be the first choice for future purchases. & \\
\cline { 2 - 3 } & Doing more business with the site in upcoming months. & \\
\hline
\end{tabular}

Based on these observations, we hypothesize:

H6. E-service quality positively influences e-loyalty in online stores.

H7. E-recovery positively influences e-loyalty in online stores.

\subsection{Online Repurchase Intentions}

Many studies have considered online repurchase intention, which can be defined as a customer's decision to purchase a product or service from the same company [52]. It may also refer to the act of buying new services from that company. Repeat business leads to success and increased profitability for online vendors. Recently, customer retention has attracted significant attention because it represents a competitive advantage. A number of studies focus on variables that determine repurchase intentions. The construct expresses the desire to make recurrent purchases [52]. Quality of experience, shaped by past experiences as well as the quality of purchased products and/or services, is extremely important for online customers. According to studies, repurchase intentions in the context of online shopping can be evaluated using a number of factors, the most important of which are perceptions of product information, payment methods [8], issues pertaining to delivery [44], service provision, risk, security, privacy, personalization, requests for reconsideration, transportation [64], and entertainment [41]. Thus, the following hypothesis is postulated.

\section{H8. E-loyalty positively influences online repurchase intentions in online stores.}

Based on the objectives and hypotheses of the research, the model in Figure 1 is proposed. 


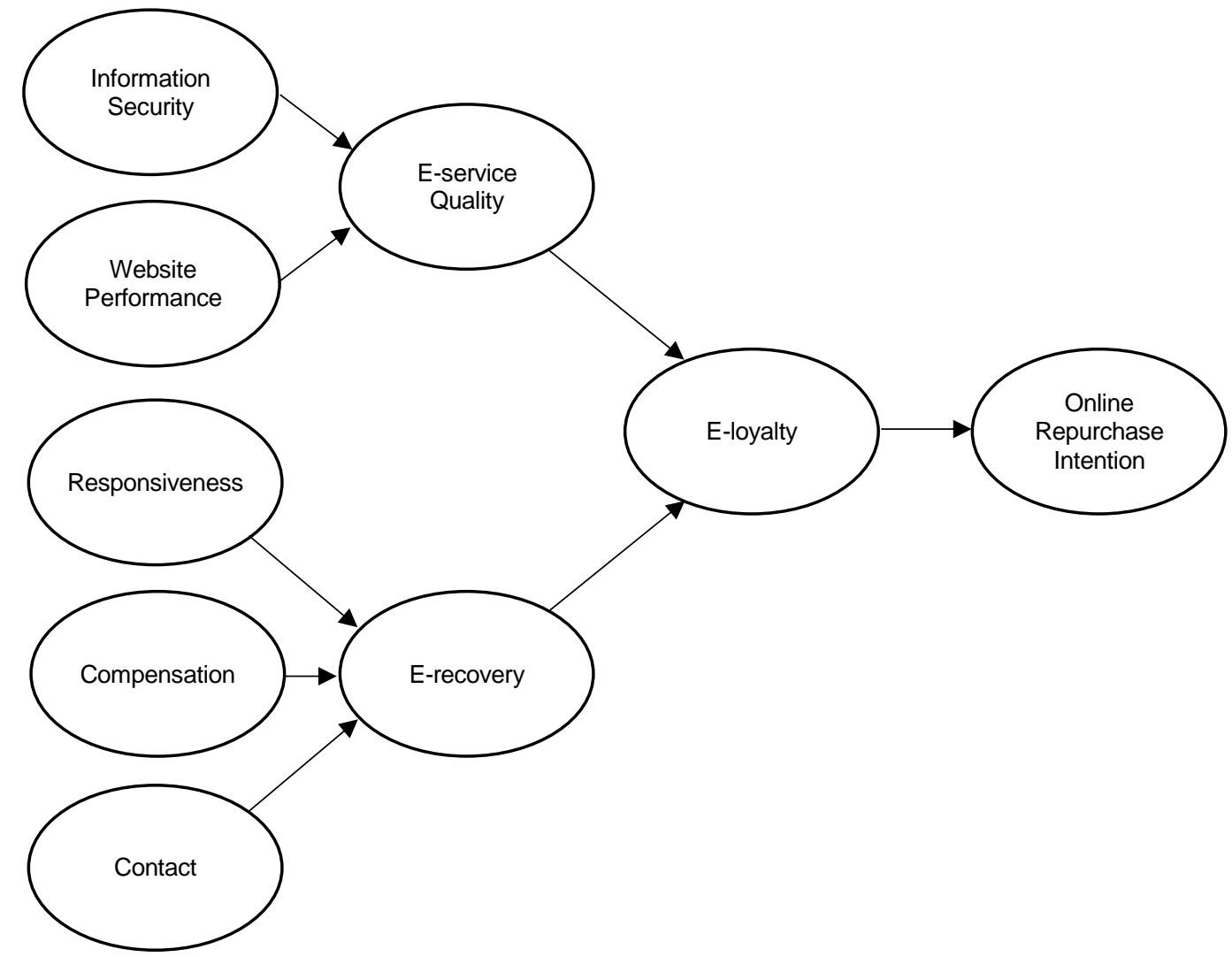

Figure 1: Research model

\section{Materials and Methods}

The present study is a survey with applied goals. It was conducted between February and August of 2015 on a group of Iranian online stores offering various goods and services. Through desk research (i.e. information sources such as books, journals, papers, and online scientific databases), the required information for identifying the variables of the study were collected and extant literature was reviewed. A questionnaire, developed by the authors, was used to assess the relationships between the variables. Face validity of the instrument was confirmed. In developing the questionnaire, theoretical background of the study was reviewed and necessary indices were identified. Thereafter, several university professors and subject area experts were asked to review the developed questionnaire and their comments were then obtained via separate interviews at their offices. The relevant issues pointed out by the experts were applied to increase the clarity of the questionnaire and improve its contents. Furthermore, in order to demonstrate reliability, Cronbach's alpha was calculated, yielding values greater than 70 percent for each of the variables, as shown in Table 4 [48].

Table 4: Reliability coefficients

\begin{tabular}{|l|l|}
\hline Variable & Cronbach's alpha \\
\hline Information Security & 0.74 \\
\hline Website Performance & 0.87 \\
\hline E-service Quality & 0.81 \\
\hline Responsiveness & 0.73 \\
\hline Compensation & 0.77 \\
\hline Contact & 0.80 \\
\hline E-recovery & 0.77 \\
\hline E-loyalty & 0.88 \\
\hline Online Repurchase Intention & 0.91 \\
\hline Total & 0.83 \\
\hline
\end{tabular}

The statistical population includes customers of various Iranian online stores, of which a random sample was drawn. Stratified sampling was conducted and sample size was determined using Partial Least Squares Structural Equation Modeling (PLS-SEM), yielding 50. A frequently used rule for setting a lower bound on sample size was proposed by Barclay et al. [6]. According to this rule, minimum sample size for PLS equals the larger of the following: (1) ten times the number of indicators of the scale with the largest number of formative indicators in the measurement models of the research model, or (2) ten times the largest number of structural paths directed at a particular variable. As shown 
in Table 2, responsiveness and e-loyalty have the largest number of indicators i.e. five. Thus, using the first part of the rule, minimum sample size equals five times ten or fifty. E-loyalty has the greatest number of paths i.e. four; the second part of rule suggests that minimum sample size equals four times ten or forty. Comparing the two numbers, the larger one, i.e. 50, is chosen as a lower bound for sample size. For data collection, the developed questionnaire was used in a real online store and visitors were asked to participate in the survey. A total of 80 questionnaires were completed by the users; however, 50 sets of answers were used for analysis purposes.

Table 5 summarizes the demographic characteristics of the sample.

Table 5: Demographic characteristics of the sample

\begin{tabular}{|c|c|c|c|}
\hline Variable & Dimensions & Quantity & Percentage \\
\hline \multirow{2}{*}{ Gender } & Female & 22 & $44 \%$ \\
\hline & Male & 28 & $56 \%$ \\
\hline \multirow{5}{*}{ Age } & $<20$ & 2 & $4 \%$ \\
\hline & $21-30$ & 16 & $32 \%$ \\
\hline & $31-40$ & 20 & $40 \%$ \\
\hline & $41-50$ & 12 & $24 \%$ \\
\hline & $>51$ & 0 & $0 \%$ \\
\hline \multirow{4}{*}{ Education } & High school diploma & 2 & $4 \%$ \\
\hline & Bachelor's degree & 14 & $28 \%$ \\
\hline & Master's degree & 17 & $35 \%$ \\
\hline & PhD & 17 & $35 \%$ \\
\hline \multirow{4}{*}{ Job } & Student & 32 & $64 \%$ \\
\hline & Employee & 4 & $8 \%$ \\
\hline & Teacher or University Professor & 8 & $16 \%$ \\
\hline & Other & 6 & $12 \%$ \\
\hline
\end{tabular}

\section{Data Analysis and Findings}

In this section, the data obtained via the study questionnaire is analyzed and the research findings is presented in detail. First, the fitness of the research model is examined and then the research hypotheses is tested.

\subsection{Model Fit}

This paper employs PLS-SEM to determine model fit and test the postulated hypotheses. Hair et al. [29] propose two criteria for evaluating formative models: (1) significance of item factor loadings assessed through t-values and (2) multi-collinearity between indicators. In the following, the criteria are investigated in the context of this paper. The correlation matrix of the study variables is shown in Table 6.

Table 6: Correlation matrix

\begin{tabular}{|l|l|l|l|l|l|l|l|l|l|}
\hline & Compensation & Contact & E-loyalty & E-recovery & $\begin{array}{l}\text { E-service } \\
\text { Quality }\end{array}$ & $\begin{array}{l}\text { Information } \\
\text { Security }\end{array}$ & $\begin{array}{l}\text { Repurchase } \\
\text { Intention }\end{array}$ & Responsiveness & $\begin{array}{l}\text { Website } \\
\text { Performance }\end{array}$ \\
\hline Compensation & 1.000 & & & & & & & & \\
\hline Contact & 0.351 & 1.000 & & & & & & & \\
\hline E-loyalty & 0.116 & 0.208 & 1.000 & & & & & & \\
\hline E-recovery & 0.713 & 0.532 & 0.77 & 1.000 & & & & & \\
\hline $\begin{array}{l}\text { E-service } \\
\text { Quality }\end{array}$ & 0.249 & 0.356 & 0.624 & 0.246 & 1.000 & & & & \\
\hline $\begin{array}{l}\text { Information } \\
\text { Security }\end{array}$ & 0.292 & 0.339 & 0.539 & 0.266 & 0.882 & 1.000 & & & \\
\hline $\begin{array}{l}\text { Repurchase } \\
\text { Intention }\end{array}$ & 0.183 & 0.133 & 0.545 & 0.203 & 0.434 & 0.331 & 1.000 & & \\
\hline Responsiveness & 0.241 & 0.228 & -0.034 & 0.816 & 0.082 & 0.076 & 0.117 & 1.000 & \\
\hline $\begin{array}{l}\text { Website } \\
\text { Performance }\end{array}$ & 0.112 & 0.256 & 0.563 & 0.159 & 0.865 & 0.569 & 0.365 & 0.047 & 1.000 \\
\hline
\end{tabular}

\subsubsection{Significance of Item Factor Loadings}

If t-values for items of a construct with formative indicators are smaller than 1.96, the items can be removed from the model, with 95 percent confidence. However, this must be carried out after giving due consideration to the theoretical background of the study, expert opinions, and content validity [17]. As demonstrated in Figure 2, all t-values exceed 1.96 . 


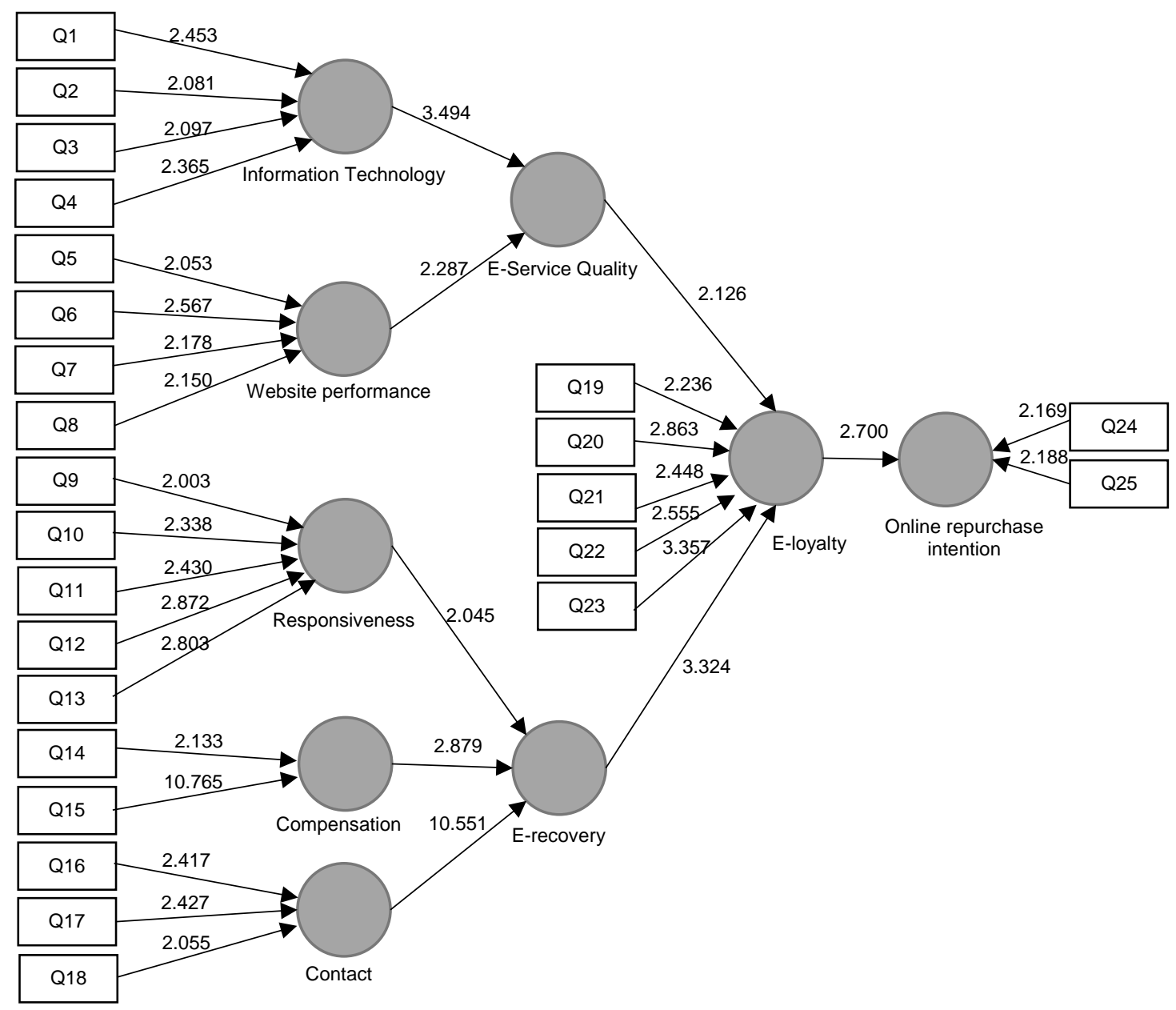

Figure 2: Model assessment using formative indicators with t-values

Table 7: VIF values

\begin{tabular}{|l|l|l|}
\hline Construct & Indicator & VIF \\
\hline \multirow{5}{*}{ Information Security } & $\mathrm{Q}_{1}$ & 1.126 \\
\cline { 2 - 3 } & $\mathrm{Q}_{2}$ & 1.116 \\
\cline { 2 - 3 } & $\mathrm{Q}_{3}$ & 1.096 \\
\cline { 2 - 3 } & $\mathrm{Q}_{4}$ & 1.138 \\
\hline \multirow{5}{*}{ Website Performance } & $\mathrm{Q}_{5}$ & 1.471 \\
\cline { 2 - 3 } & $\mathrm{Q}_{6}$ & 1.070 \\
\cline { 2 - 3 } & $\mathrm{Q}_{7}$ & 1.418 \\
\cline { 2 - 3 } & $\mathrm{Q}_{8}$ & 1.515 \\
\hline \multirow{5}{*}{ Responsiveness } & $\mathrm{Q}_{9}$ & 1.077 \\
\cline { 2 - 3 } & $\mathrm{Q}_{10}$ & 1.874 \\
\cline { 2 - 3 } & $\mathrm{Q}_{11}$ & 1.589 \\
\cline { 2 - 3 } & $\mathrm{Q}_{12}$ & 1.966 \\
\cline { 2 - 3 } & $\mathrm{Q}_{13}$ & 1.346 \\
\hline \multirow{5}{*}{ Compensation } & $\mathrm{Q}_{14}$ & 1.378 \\
\cline { 2 - 3 } & $\mathrm{Q}_{15}$ & 3.829 \\
\hline \multirow{5}{*}{ E-loyalty } & $\mathrm{Q}_{16}$ & 1.065 \\
\cline { 2 - 3 } & $\mathrm{Q}_{17}$ & 1.267 \\
\cline { 2 - 3 } & $\mathrm{Q}_{18}$ & 1.312 \\
\hline & $\mathrm{Q}_{19}$ & 1.363 \\
\cline { 2 - 3 } & $\mathrm{Q}_{20}$ & 1.780 \\
\cline { 2 - 3 } & $\mathrm{Q}_{21}$ & 1.403 \\
\cline { 2 - 3 } & $\mathrm{Q}_{22}$ & 1.331 \\
\cline { 2 - 3 } & $\mathrm{Q}_{23}$ & 2.606 \\
\hline \multirow{5}{*}{ Online Repurchase Intention } & $\mathrm{Q}_{24}$ & 1.648 \\
\cline { 2 - 3 } & $\mathrm{Q}_{25}$ & 1.648 \\
\hline
\end{tabular}




\subsubsection{Multicollinearity between Indicators}

High multicollinearity between indicators may signal inadequate model fit. Thus, it is necessary to identify the indicators that cause this multicollinearity and decide whether they should be eliminated. Multicollinearity is detected using Variance Inflation Factor (VIF). Values equal to or larger than five imply that at least 80 percent of the extent to which an indicator defines a construct, can also be expressed using other indicators. Therefore, the indicator may not be relevant [11], [18], [25]. VIF is calculated according to Equation 1. VIF values for model indicators are shown in Table 7.

$$
\text { VIF (Indicators })=\frac{1}{1-\mathrm{R}^{2}}
$$

As seen in Table 8, according to VIF, the study variables show no significant collinearity.

Table 8: Collinearity of variables based on VIF

\begin{tabular}{|l|l|l|l|l|}
\hline & E-loyalty & E-recovery & $\begin{array}{l}\text { E-service } \\
\text { Quality }\end{array}$ & $\begin{array}{l}\text { Repurchase } \\
\text { Intention }\end{array}$ \\
\hline Compensation & & 1.177 & & \\
\hline Contact & & 1.17 & & \\
\hline E-loyalty & & & & 1.00 \\
\hline E-recovery & 1.075 & & & \\
\hline $\begin{array}{l}\text { E-service } \\
\text { Quality }\end{array}$ & 1.075 & & 1.48 & \\
\hline $\begin{array}{l}\text { Information } \\
\text { Security }\end{array}$ & & & & \\
\hline $\begin{array}{l}\text { Repurchase } \\
\text { Intention }\end{array}$ & & 1.089 & & \\
\hline $\begin{array}{l}\text { Responsiveness } \\
\text { Website } \\
\text { Performance }\end{array}$ & & & 1.48 & \\
\hline
\end{tabular}

The overall model was examined using Goodness of Fit (GOF) proposed by Tenenhaus et al. [61]. GOF is compared to the three values of $0.01,0.25,0.36$ introduced as weak, medium, and strong, respectively, by Wetzels et al. [63]. The value 0.314 (calculated according to Equation 2) is indicative of acceptable GOF.

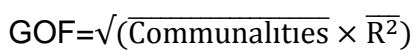

\subsection{Hypothesis Testing}

According to the analysis algorithm in PLS, subsequent to establishing model fit, the postulated hypotheses need to be tested. This is done in the following subsections.

\subsubsection{T-values}

Path coefficients are used to assess the significance of the hypotheses. As depicted in Figure 2, the coefficient for the path between e-loyalty and online repurchase intention equals 2.700 . This value, which exceeds 1.96 , confirms the significant impact of e-loyalty on online repurchase intention, with 95 percent confidence. Thus, the corresponding hypothesis (i.e. H8) is supported. In a similar vein, t-values of information security (H1), website performance $(\mathrm{H} 2)$, responsiveness $(\mathrm{H} 3)$, compensation $(\mathrm{H} 4)$, contact $(\mathrm{H} 5)$, e-service quality $(\mathrm{H} 6)$, and e-recovery $(\mathrm{H} 7)$ equal 3.494, 2.287, 2.045, 2.879, 10.551, 2.126 and 3.324 respectively. These seven hypotheses are supported.

\subsubsection{Standardized Factor Loading Coefficients}

The path between two latent variables is examined using t-values in order to ascertain the existence of a significant positive impact. In this step, the extent to which one variable explains the variation in another is determined. According to Figure 3, 27 percent of the variations in e-loyalty can be explained using online repurchase intention. Furthermore, information security and website performance account for 40 and 29 percent of e-service quality variation, respectively. Also, 15 percent of the variation in e-recovery is explained by responsiveness, while compensation and contact account for 20 and 58 percent, respectively. Finally, e-service quality and e-recovery account for 16 and 39 percent of e-loyalty variation, respectively. Table 9 summarizes the results of testing the hypotheses. 
Table 9: Hypotheses test results

\begin{tabular}{|l|l|l|l|l|}
\hline No & Hypothesis & Path coefficient & $\mathrm{t}$ & Result \\
\hline 1 & Information security will influence e-service quality. & 0.397 & 3.494 & Supported \\
\hline 2 & Website performance will influence e-service quality. & 0.287 & 2.287 & Supported \\
\hline 3 & Responsiveness will influence e-recovery. & 0.154 & 2.045 & Supported \\
\hline 4 & Compensation will influence e-recovery. & 0.202 & 2.879 & Supported \\
\hline 5 & Contact will influence e-recovery. & 0.580 & 10.551 & Supported \\
\hline 6 & E-service quality will influence e-loyalty. & 0.162 & 2.126 & Supported \\
\hline 7 & E-recovery will influence e-loyalty. & 0.392 & 3.324 & Supported \\
\hline 8 & E-loyalty will influence online repurchase intentions. & 0.272 & 2.700 & Supported \\
\hline
\end{tabular}

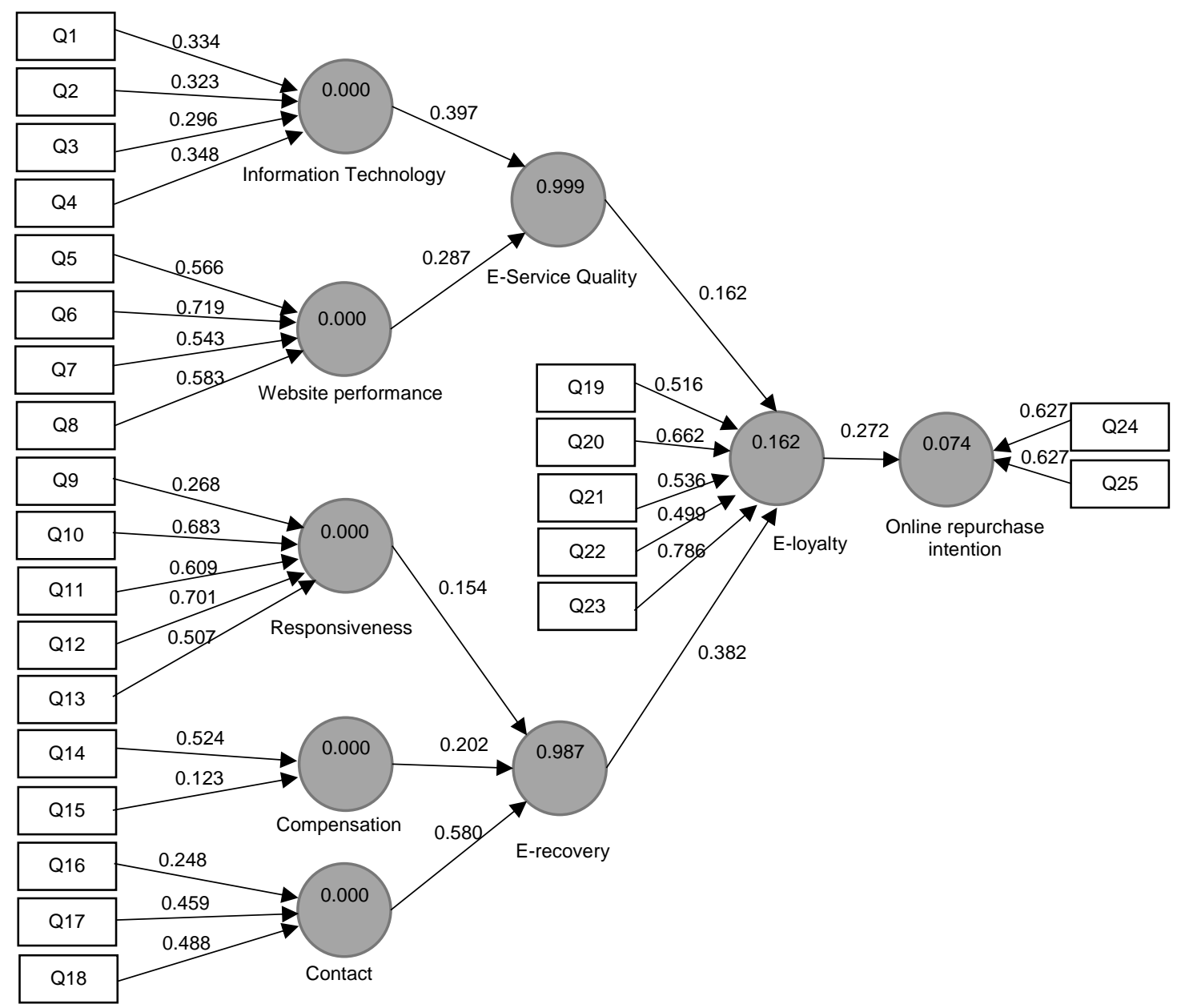

Figure 3: Model assessment with factor loadings

\section{Conclusion}

In the modern business world, developments in science and technology have given rise to many virtual communities with numerous objectives. Initially, such communities were formed for the purpose of entertainment or exchange of information; however, current websites allow commercial transactions of varying sizes to take place. Trust is a critical factor in the development of e-commerce. Once trust is established between customers and online merchants, a large number of factors may influence the retention and repurchase intentions of those customers. Our findings indicate that e-service quality and compensation of low-quality services are decisive factors in creating customer satisfaction. In this paper, factors leading to e-service quality, e-recovery, and subsequently e-loyalty were discussed at length. According to the results, e-service quality, influenced by website performance and information security, impacts customer loyalty. Moreover, e-recovery, which is affected by responsiveness, compensation, and contact, can lead to improved customer satisfaction. This in turn increases online repurchase intentions ultimately resulting in long-term profits. The research findings are consistent with those of other studies including Sur [60], Giovanis and Athanasopoulou [23], Ha and Stoel [27], Kim et al. [36], Lee and Lin [37], and Anderson and Srinivasan [2]. Bernardo et al. [7] also investigated the impact of improving service quality on customer satisfaction and loyalty in the context 
of online shopping. Focusing on online travel agencies, the authors concluded that both service quality and improvement affect customer satisfaction and loyalty. However, service quality seems to have a greater impact.

Managers and owners of online stores are recommended to keep their customers satisfied in order to increase profitability. Thus, they must strive to maintain and improve e-service quality. In order to improve their service quality, online sellers need to make sure that customer information, especially banking information, remains confidential. Also, purchased items must be delivered as promised. Another factor that influences service quality is the website's design. Therefore, the website must be well-structured and easy-to-use so that visitors can locate their intended items in a short time. In the modern world, where online stores and online shopping are increasing every day, the significance of trust is growing too. Trust is especially important in online context where goods are sold without direct contact. The topic has not been fully investigated in some developing countries including Iran where online shopping is not as well accepted as developed countries.

As mentioned earlier, service improvement is among the factors, which influence customer loyalty. Therefore, online merchants need to provide customers with adequate options to return deficient products. Furthermore, customers must be reimbursed in case of damages or delays. Finally, customers must be able to contact the website's call center at any time and talk to specialized personnel about their problems.

As with any scientific endeavor, this study also had some limitations. The most important challenge was the lack of interest from visitors to participate in the study. Although the owners of the online stores were kind enough to cooperate with the authors, many visitors refused to answer the questionnaire by giving reasons such as lack of time or inability to trust the authors. This lack of participation resulted in a small sample size.

In the future, other studies with larger samples need to be conducted on other online stores to verify the results of this study and identify potential problems. Furthermore, other variables that may lead to loyalty in online stores need to be discovered and added to the present model. Thus, the combination of results from this study and future studies can lead to solutions that are more concrete for owners of online stores. Moreover, a large number of variables may influence service quality. Future studies should consider these factors. The proposed model should also be examined in other countries and geographical areas to extend and compare the results of this study. E-trust has been shown to influence customer loyalty, which in turn increases online shopping. Thus, it is recommended that future studies investigate e-trust and its components.

\section{Acknowledgments}

We would like to gratefully acknowledge the Office of Graduate Studies of the University of Isfahan for their support.

\section{References}

[1] M. Ahmad Al-Hawari, Does customer sociability matter? Differences in e-quality, e-satisfaction, and e-loyalty between introvert and extravert online banking users. Journal of Services Marketing. vol. 28, no. 7, pp. 538-546 2014.

[2] R. E. Anderson and S. S. Srinivasan, E-satisfaction and e-loyalty: a contingency framework, Psychology and Marketing, vol. 20, no. 2, pp. 123-138, 2003

[3] M. S. M. Ariff, L. O. Yun and N. Zakuan, The impacts of service quality and customer satisfaction on customer loyalty in internet banking, Procedia-Social and Behavioral Sciences, vol. 81, pp. 469-473, 2013.

[4] A. Attafar and H. Mansouri, Model of improving customer loyalty in electronic stores, New Marketing Research Journal, vol. 1, no. 3, pp. 145-163, 2011.

[5] A. Baldinger and J. Rubinson, Brand loyalty: The link between attitude and behavior, Journal of Advertising Research, vol. 36, no. 6, pp. 22-35, 1996.

[6] D. Barclay, C. Higgins and R. Thompson, The partial least squares (PLS) approach to causal modeling: Personal computer adoption and use as an illustration, Technology Studies, vol. 2, no. 2, pp. 285-309, 1995.

[7] M. Bernardo, J. Llach, F. Marimon, and M. M. Alonso-Almeida, The balance of the impact of quality and recovery on satisfaction: The case of e-travel, Total Quality Management \& Business Excellence, vol. 24, pp. 1390-1404, 2013.

[8] M. Blut, C. M. Frennea, V. Mittal, and D. L. Mothersbaugh, How procedural, financial and relational switching costs affect customer satisfaction, repurchase intentions, and repurchase behavior: A meta-analysis, International Journal of Research in Marketing, vol. 32, no. 2, pp. 226-229, 2015.

[9] G. Bressolles, F. Durrieu and S. Senecal, A consumer typology based on e-service quality and e-satisfaction, Journal of Retailing and Consumer Services, vol. 21, no. 6, pp. 889-896, 2014.

[10] A. Caruana and L. Pitt, INTQUAL-an internal measure of service quality and the link between service quality and business performance, European Journal of Marketing, vol. 31, no. 8, pp. 604-616, 1997.

[11] C. Cassel, P. Hackl and A. H. Westlund, Robustness of partial least-squares method for estimating latent variable quality structures, Journal of Applied Statistics, vol. 26, no. 4, pp. 435-446, 1999.

[12] J.-S. Chiu, Strategic Marketing Analysis: Framework and Practical Applications. Taipei: BEST WISE, 2006. 
[13] B. J. Corbitt, T. Thanasankit and H. Yi, Trust and e-commerce: A study of consumer perceptions, Electronic Commerce Research and Applications, vol. 2, no. 3, pp. 203-215, 2003.

[14] C. L. Corritore, B. Kracher and S. Wiedenbeck, On-line trust: Concepts, evolving themes, a model, International Journal of Human-Computer Studies, vol. 58, no. 6, pp. 737-758, 2003.

[15] E. Cristobal, C. Flavián and M. Guinalíu, Perceived e-service quality (PeSQ) measurement validation and effects on consumer satisfaction and web site loyalty, Managing Service Quality: An International Journal, vol. 17, no. 3, pp. 317-340, 2007.

[16] M. A. Davenport, J. E. Leahy, D. H. Anderson, and P. J. Jakes, Building trust in natural resource management within local communities: A case study of the midewin national tallgrass prairie, Environmental Management, vol. 39, no. 3, pp. 353-368, 2007.

[17] A. Diamantopoulos and J. A. Siguaw, Formative versus reflective indicators in organizational measure development: A comparison and empirical illustration, British Journal of Management, vol. 17, no. 4, pp. 263282, 2006.

[18] A. Diamantopoulos and H. M. Winklhofer, Index construction with formative indicators: An alternative to scale development, Journal of Marketing Research, vol. 38, no. 2, pp. 269-277, 2001.

[19] B. Durmuş, Y. Ulusu and S. Erdem, Which dimensions affect private shopping e-customer loyalty?, ProcediaSocial and Behavioral Sciences, vol. 99, pp. 420-427, 2013.

[20] M. Fassnacht and I. Köse, Consequences of web-based service quality: Uncovering a multi-faceted chain of effects, Journal of Interactive marketing, vol. 21, no. 3, pp. 35-54, 2007.

[21] C. Folkman Curasi and K. Norman Kennedy, From prisoners to apostles: A typology of repeat buyers and loyal customers in service businesses, Journal of Services Marketing, vol. 16, no. 4, pp. 322-341, 2002.

[22] I. Geyskens, J.-B. E. Steenkamp and N. Kumar, Generalizations about trust in marketing channel relationships using meta-analysis, International Journal of Research in Marketing, vol. 15, no. 3, pp. 223-248, 1998.

[23] A. N. Giovanis and P. Athanasopoulou, Gaining customer loyalty in the e-tailing marketplace: The role of eservice quality, e-satisfaction and e-trust, International Journal of Technology Marketing, vol. 9, no. 3, pp. 288304, 2014.

[24] E. E. Grandon and J. M. Pearson, Electronic commerce adoption: an empirical study of small and medium US businesses, Information \& management, vol. 42, no. 1, pp. 197-216, 2004.

[25] R. Grewal, J. A. Cote and H. Baumgartner, Multicollinearity and measurement error in structural equation models: Implications for theory testing, Marketing Science, vol. 23, no. 4, pp. 519-529, 2004.

[26] C. Grönroos, Relationship marketing: Strategic and tactical implications, Management Decision, vol. 34, no. 3, pp. 5-14. 1996.

[27] S. Ha and L. Stoel, Online apparel retailing: Roles of e-shopping quality and experiential e-shopping motives, Journal of Service Management, vol. 23, no. 2, pp. 197-215, 2012.

[28] P. Haertsch, P. Schubert and D. Selz, Digital Elforgreich. Berlin: Springer, 2002.

[29] J. F. Hair, C. M. Ringle and M. Sarstedt, PLS-SEM indeed a silver bullet, Journal of Marketing Theory \& Practice, vol. 19, no. 2, pp. 135-147, 2011.

[30] M. Hamidizadeh, A. Hajikarimi and M. Naeiji, Designing and explaining the model of persistent customer loyalty in e-commerce: A study in the e-retailer's web sites, New Marketing Research Journal, vol. 1, no. 2, pp. 79-92, 2011.

[31] D. L. Hoffman and T. P. Novak, Marketing in hypermedia computer-mediated environments: Conceptual foundations, The Journal of Marketing, vol. 60, no. 3, pp. 50-68, 1996.

[32] L. T. Hosmer, Trust: The connecting link between organizational theory and philosophical ethics, Academy of Management Review, vol. 20, no. 2, pp. 379-403, 1995.

[33] F. M. Hsu, T. Y. Chen, C. T. Fan, C. M. Lin, and C. M. Chiu, Factors affecting the satisfaction of an online community for archive management in Taiwan, Program: Electronic Library and Information Systems, vol. 49, no. 1 , pp. 46-62, 2015.

[34] N. Ilkhani, S. Soltani and M. H. M. Jamshidi, Examining a hybrid model for e-satisfaction and e-loyalty to e ticketing on airline websites, Journal of Air Transport Management, vol. 37, pp. 36-44, 2014.

[35] S. A. Khan, Y. Liang and S. Shahzad, An empirical study of perceived factors affecting customer satisfaction to re-purchase intention in online stores in China, Journal of Service Science and Management, vol. 8, no. 3, pp. $291,2015$.

[36] J. Kim, B. Jin and J. L. Swinney, The role of retail quality, e-satisfaction and e-trust in online loyalty development process, Journal of Retailing and Consumer Services, vol. 16, no. 4, pp. 239-247, 2009.

[37] G. G. Lee and H. F. Lin, Customer perceptions of e-service quality in online shopping, International Journal of Retail \& Distribution Management, vol. 33, no. 2, pp. 161-176, 2005.

[38] H. Y. Lee, H. Ahn, H. K. Kim, and J. Lee, Comparative analysis of trust in online communities, Procedia Computer Science, vol. 31, pp. 1140-1149, 2014.

[39] B. R. Lewis and P. McCann, Service failure and recovery: Evidence from the hotel industry, International Journal of Contemporary Hospitality Management, vol. 16, no. 1, pp. 6-17, 2004.

[40] H. Li and R. Suomi, A proposed scale for measuring e-service quality, International Journal of U-and E-Service, Science and Technology, vol. 2, no. 1, pp. 1-10, 2009.

[41] C. Lin and W. Lekhawipat, Factors affecting online repurchase intention, Industrial Management \& Data Systems, vol. 114, no. 4, pp. 597-611, 2014

[42] G. T. Lin and C. C. Sun, Factors influencing satisfaction and loyalty in online shopping: An integrated model, Online Information Review, vol. 33, no. 3, pp. 458-475, 2009. 
[43] N. Luhmann, Familiarity, confidence, trust: Problems and alternatives, Trust: Making and Breaking Cooperative Relations, vol. 6, pp. 94-107, 2000.

[44] H. Luo, X. Han, J. Wang, and L. Liu, The moderating effect of perceived quality of logistics services and gender in the relationship between trust satisfaction and repurchase intention in e-commerce, presented at the Service Systems and Service Management (ICSSSM), 12th International Conference on, Guangzhou, 22-24 June, 2015.

[45] J. G. Maxham III, Service recovery's influence on consumer satisfaction, positive word-of-mouth, and purchase intentions, Journal of Business Research, vol. 54, no. 1, pp. 11-24, 2001.

[46] R. C. Mayer and M. B. Gavin, Trust in management and performance: Who minds the shop while the employees watch the boss? Academy of Management Journal, vol. 48, no. 5, pp. 874-888, 2005.

[47] J. L. Miller, C. W. Crighead and K. R. Karwan, Service recovery: A framework and empirical investigation, Journal of Operations Management, vol. 18, no. 4, pp. 387-400, 2000.

[48] J. Nunnally, Psychometric Theory (2nd Ed.). New York: McGraw-Hill, 1978.

[49] P. Oliveira, A. V. Roth and W. Giland, Achieving competitive capabilities in e-services, Technological Forecasting and Social Change, vol. 69, no. 7, pp. 721-739, 2002.

[50] A. Parasuraman, V. A. Zeithaml, and A. Malhotra, ES-QUAL: A multiple-item scale for assessing electronic service quality, Journal of service research, vol. 7, no. 3, pp. 213-233, 2005.

[51] J. Preece, Online Communities: Designing Usability and Supporting Sociability. New Jersey: John Wiley \& Sons, Inc., 2000.

[52] N. S. A. Razak, M. Marimuthu, A. Omar, and M. Mamat, Trust and repurchase intention on online tourism services among Malaysian consumers, Procedia-Social and Behavioral Sciences, vol. 130, pp. 577-582, 2014.

[53] C. M. Ridings, D. Gefen and B. Arinze, Some antecedents and effects of trust in virtual communities, The Journal of Strategic Information Systems, vol. 11, no. 3, pp. 271-295, 2002.

[54] C. Romm, N. Pliskin and R. Clarke, Virtual communities and society: Toward an integrative, three phase model, International Journal of Information Management, vol. 17, no. 4, pp. 261-270, 1997.

[55] J. B. Rotter, Interpersonal trust, trustworthiness, and gullibility, American Psychologist, vol. 35, no. 1, p. 1-7, 1980.

[56] N. S. Safa and M. A. Ismail, A customer loyalty formation model in electronic commerce, Economic Modelling, vol. 35, no. 1, pp. 559-564, 2013.

[57] A. Seyed Naghavi and G. Shakiba Jamalabad, Pattern of identifying factors affecting formation process of customer loyalty in electronic stores, Management Researches Journal, vol. 4, no. 12, pp. 95-110, 2011.

[58] M. M. Shafiee, A. Sanayei, A. Shahin, and H. R. Dolatabadi, The role of brand image in forming airlines passengers' purchase intention: Study of Iran aviation industry, International Journal of Services and Operations Management, vol. 19, no. 3, pp. 360-37, 2014

[59] S. Shan, Y. Li, L. Liu and Z. Mao, Empirical study on influential factors of knowledge sharing on emergency events in virtual communities, Advances in information Sciences and Service Sciences, vol. 4, no. 9, pp. 137154, 2012.

[60] S. Sur, The role of online trust and satisfaction in building loyalty towards online retailers: Differences between heavy and light shopper groups, in Proceedings 4th International Conference on Logistics, Informatics and Service Science, Berkeley, California, 2015.

[61] M. Tenenhaus, S. Amato and V. Esposito Vinzi, A global goodness-of-fit index for PLS structural equation modelling, in Proceedings of the XLII SIS scientific meeting, Padova, 2004, pp. 739-742.

[62] P. Thaichon, A. Lobo and A. Mitsis, Achieving customer loyalty through service excellence in internet industry, International Journal of Quality and Service Sciences, vol. 6, no. 4, pp. 274-289, 2014.

[63] M. Wetzels, G. Odekerken-Schröder and C. Van Oppen, Using PLS path modeling for assessing hierarchical construct models: Guidelines and empirical illustration, MIS Quarterly, vol. 33, no. 1, pp. 177-195, 2009.

[64] S. Yang, Y. Lu, P. Chau, and S. Gupta, Role of channel integration on the service quality, satisfaction, and repurchase intention in a multi-channel (online-cum-mobile) retail environment, Electronic Commerce Research Journal, (Forthcoming), vol. 15, no. 1, pp. 1-25, 2015

[65] L. Yin and L. Liu, A conceptual model for investigating online group buying in virtual communities, Advances in Information Sciences \& Service Sciences, vol. 4, no. 8, pp. 231- 257, 2012.

[66] B. Yoo and N. Donthu, Developing a scale to measure the perceived quality of an Internet shopping site (SITEQUAL), Quarterly Journal of Electronic Commerce, vol. 2, pp. 31-45, 2001.

[67] C. Zehir, Y. Sehitoglu, E. Narcikara, and S. Zehir, ES-Quality, perceived value and loyalty intentions relationships in internet retailers, Procedia-Social and Behavioral Sciences, vol. 150, pp. 1071-1079, 2014. 